KEWENANGAN MENGADILI OLEH HAKIM PRA PERADILAN TENTANG PENETAPAN SESEORANG MENJADI TERSANGKA DALAM PERKARA TINDAK PIDANA KORUPSI DANA PROGRAM PENYEDIAAN DAN PENGEMBANGAN SARANA DAN PRASARANA PERTANIAN PASCA PUTUSAN MK NOMOR 21/PUU-XII/2014

(Studi Putusan Perkara Nomor 3/Pid/Pra/2018/PN.Mgl)

Jurnal Penelitian

Oleh:

WAYAN EKA PURWATI

NPM. 15211102

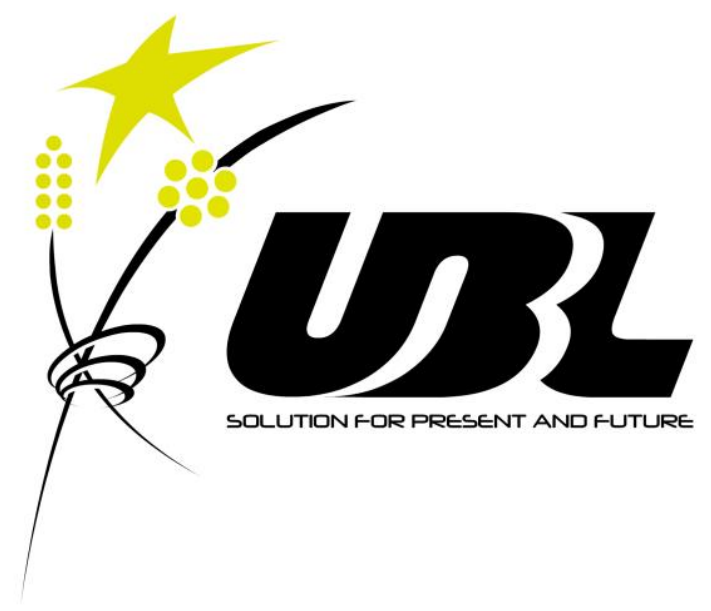

FAKULTAS HUKUM

UNIVERSITAS BANDAR LAMPUNG

2019 


\section{ABSTRAK \\ KEWENANGAN MENGADILI OLEH HAKIM PRA PERADILAN TENTANG PENETAPAN SESEORANG MENJADI TERSANGKA DALAM PERKARA TINDAK PIDANA KORUPSI DANA PROGRAM PENYEDIAAN DAN PENGEMBANGAN SARANA DAN PRASARANA PERTANIAN PASCA PUTUSAN MK NOMOR 21/PUU-XII/2014 (Studi Putusan Perkara Nomor 3/Pid/Pra/2018/PN.Mgl)}

\section{Oleh: WAYAN EKA PURWATI}

Salah satu contoh permohonan pra peradilan adalah pada Putusan Perkara Nomor 3/Pid/Pra/2018/PN.Mgl, dimana pada putusan tersebut dimohonkan agar Ketua Pengadilan Negeri Menggala Cq. Hakim Tunggal Praperadilan yang memeriksa dan mengadili permohonan ini dapat menjatuhkan putusan

Permasalahan dalam penelitian adalah Bagaimana proses penyidikan tindak pidana korupsi dana program penyediaan dan pengembangan sarana dan prasarana pertanian di Dinas Pertanian, Perkebunan dan Kehutanan Kabupaten Tulang Bawang, Bagaimana kewenangan mengadili oleh Hakim Pra Peradilan tentang penetapan seseorang menjadi tersangka dalam perkara tindak pidana korupsi dan Bagaimana akibat hukum putusan pra peradilan terhadap penetapan seseorang menjadi tersangka dalam perkara tindak pidana korupsi.

Metode penelitian menggunakan pendekatan yuridis normatif dan empiris, pendekatan yuridis normatif dilaksanakan dengan mempelajari norma atau kaidah hukum, asas-asas hukum, sedangkan pendekatan empiris dilakukan dengan wawancara langsung terhadap narasumber yang akan berhubungan dengan masalah penelitian, analisis data yang digunakan adalah analisis kualitatif.

Hasil penelitian menunjukkan Proses penyidikan tindak pidana korupsi dana program penyediaan dan pengembangan sarana dan prasarana pertanian di Dinas Pertanian, Perkebunan dan Kehutanan Kabupaten Tulang Bawang sudah sesuai dengan ketentuan yang ada di dalam Kitab Undang-Undang Hukum Acara Pidana, khususnya Pasal 77 KUHAP yang mengatur objek Praperadilan, dimana Pengadilan Negeri Menggala $C q$. Hakim Tunggal Praperadilan yang memeriksa dan mengadili permohonan ini berpendapat lain, mohon putusan yang seadiladilnya (ex aequo et bono). Kewenangan mengadili oleh Hakim Pra Peradilan tentang penetapan seseorang menjadi tersangka dalam perkara tindak pidana korupsi dana program penyediaan dan pengembangan sarana dan prasarana pertanian telah mempertimbangkan bahwa Pengadilan Negeri Menggala Cq. Hakim Tunggal Praperadilan yang memeriksa dan mengadili permohonan ini berpendapat lain, mohon putusan yang seadil-adilnya (ex aequo et bono). Akibat hukum dikabulkannya permohonan pra peradilan tentang sah tidaknya penetapan tersangka oleh penyidik berdasarkan pertimbangan bahwa penetapan status tersangka merupakan bagian dari penyidikan dan Pasal 82 ayat (3) Kitab Undang-Undang Hukum Acara Pidana. 


\section{Wayan Eka Purwati}

Saran, diharapkan kepada penyidik disarankan untuk melaksanakan penyidikan secara berdasarkan ketentuan hukum acara pidana yang berlaku dalam rangka mengantisipasi permohonan praperadilan, sehingga tindakan yang dilakukan oleh penyidik dapat berjalan efektif dan efisien dalam rangka penegakan hukum. Apabila dikeluarkan Surat Perintah Penghentian (SP3), maka perkara digelarkan lalu dibuat Surat Perintah Penghentian (SP3).

\section{Kata Kunci: Kewenangan Hakim; Pra Peradilan; Tindak Pidana Korupsi}

\section{A. Pendahuluan}

Peradilan pidana di Indonesia pada hakekatnya merupakan suatu sistem, hal ini dikarenakan dalam proses peradilan pidana di Indonesia terdiri dari tahapan-tahapan yang merupakan satu kesatuan utuh yang tidak dapat dipisahkan. Tahapan-tahapan dalam proses peradilan pidana tersebut merupakan suatu rangkaian, dimana tahap yang satu mempengaruhi tahapan yang lain. Rangkaian dalam proses peradilan pidana di Indonesia meliputi tindakan penyelidikan, penyidikan, penuntutan dan pemeriksaan di sidang pengadilan yang dilakukan oleh aparat penegak hukum. Dalam proses peradilan pidana di Indonesia yang memiliki kewenangan melakukan tindakan penyelidikan dan penyidikan ada pada kepolisian, sedangkan yang memiliki kewenangan untuk melakukan penuntutan adalah kejaksaan, sementara kewenangan mengadili dalam pemeriksaan di sidang pengadilan ada pada hakim.

Kewenangan-kewenangan yang dimiliki oleh hakim, kejaksaan, dan kepolisian meskipun berbeda, tetapi pada prinsipnya merupakan satu kesatuan utuh yang tidak dapat dipisahkan.Pelaksanaan kewenangankewenangan dalam proses peradilan pidana yang dilakukan oleh aparat penegak hukum tersebut, hendaknya memegang kuat asas-asas yang berlaku dalam Hukum Acara Pidana. Salah satu asas terpenting dalam hukum acara pidana ialah asas praduga tak bersalah, Berdasarkan asas praduga tak bersalah maka setiap orang yang disangka, ditangkap, ditahan, dituntut dan/atau diperiksa di sidang pengadilan wajib dianggap tidak bersalah sebelum ada putusan pengadilan yang mempunyai kekuatan hukum tetap. ${ }^{1}$

Adanya asas praduga tak bersalah tersebut sesuai dengan prinsip yang terkandung dalam pembentukkan Undang-Undang Nomor 8 Tahun 1981 tentang Hukum Acara Pidana (selanjutnya disebut KUHAP), yang dijiwai prinsip perlindungan terhadap harkat dan martabat manusia. Hal tersebut pada prinsipnya juga sesuai dengan tujuan KUHAP yaitu untuk memberi perlindungan terhadap hakhak asasi dalam keseimbangan dengan kepentingan umum. ${ }^{2}$

Salah satu bentuk perlindungan terhadap hak asasi dapat dilihat dengan adanya peraturan yang mengatur tentang Praperadilan sebagaimana diatur dalam pasal 77 sampai dengan Pasal 83 KUHAP. Praperadilan hanya merupakan suatu tambahan wewenang yang dimiliki oleh Pengadilan Negeri, yang berfungsi untuk memeriksa keabsahan dari suatu proses penanganan perkara, artinya adalah yang diperiksa dalam praperadilan

1 S. Tanusubroto. 2010. Peranan Prapeeradilan Dalam Hukum Acara Pidana. Alumni, Bandung, hlm.1

${ }^{2}$ Ibid, hlm. 1. 
bukanlah mengenai pokok dari suatu perkara. Sebagaimana diatur dalam KUHAP khususnya pasal 77 tentang Praperadilan, dimana dinyatakan bahwa : "Pengadilan negeri berwenang untuk memeriksa dan memutus, sesuai dengan ketentuan yang diatur dalam undang-undang ini tentang :

a. Sah atau tidaknya penangkapan, penahanan, penghentian penyidikan atau penghentian penuntutan;

b. Ganti rugi dan atau rehabilitasi bagi seorang yang perkara pidananya dihentikan pada tingkat penyidikan atau penuntutan."3

Munculnya Praperadilan disebabkan karena dalam menjalankan kewenangannya, aparat penegak hukum tidak terlepas dari kemungkinan untuk melakukan perbuatan yang bertentangan dengan ketentuan peraturan perundang-undangan yang berlaku. Maka lahirnya praperadilan adalah dengan tujuan untuk mengadakan tindakan pengawasan terhadap aparat penegak hukum agar dalam melakukan kewenangannya tidak melakukan penyelewengan atau penyalahgunaan wewenang. Kondisi ini pada prinsipnya sesuai dengan tujuan dari penegakan hukum, dimana dalam mekanisme penegakan hukum, aparat penegak hukum harus berorientasi pada tujuan bahwa dalam menyelenggarakan hukum sebagai suatu instrumen dari tertib sosial dan proses pelaksanaan perlindungan bagi kepentingan individu.

Adanya Praperadilan tidak langsung menyebabkan Proses Peradilan Pidana di Indonesia bebas dari tindakan sewenang-wenang yang dilakukan oleh aparat penegak hukum. Buktinya,

\footnotetext{
${ }^{3}$ Bambang Purnomo. 1988. Pola Dasar Teori dan Azas Umum Hukum Acara Pidana. Liberty, Yogyakarta, hlm.97.
}

dalam praktek masih sering ditemui adanya pelanggaran-pelanggaran dalam proses peradilan pidana di Indonesia. Pelanggaran-pelanggaran yang sering ditemui salah satunya adalah mengenai penangkapan dan penahanan yang tidak disertai dengan surat perintah penangkapan dan penahanan sebagaimana yang telah ditentukan dalam peraturan perundang-undangan yang berlaku. Terhadap kasus tersebut sering kali dijawab oleh oknum-oknum penegak hukum yang bersangkutan dengan cara membuat surat perintah penangkapan dan penahanan yang tanggalnya dimundurkan. Kondisi ini jelas sangat merugikan bagi pihak yang menjadi korban, karena pada prinsipnya untuk melakukan suatu penangkapan dan penahanan harus disertai adanya surat perintah penangkapan dan penahanan dari aparat penegak hukum yang bersangkutan. ${ }^{4}$

Pelanggaran lain yang sering terjadi dalam proses peradilan Pidana adalah mengenai penghentian penyidikan, dimana dalam kenyataan seringkali penghentian penyidikan tidak dinyatakan secara resmi, dalam arti tidak dikeluarkannya surat penghentian penyidikan oleh pihak kepolisian yang bersangkutan. Kondisi tersebut tentu menyulitkan mekanisme yuridis terhadap pelaksanaan praperadilan, karena untuk mempraperadilankan kasus tersebut diperlukan adanya bukti berupa surat penghentian penyidikan yang dikeluarkan oleh pihak kepolisian yang bersangkutan. ${ }^{5}$

\footnotetext{
${ }^{4}$ O.C. Kaligis dkk, 1997. Praperadilan Dalam Kenyataan. Djambatan, Jakarta, hlm.4. Website: www.pemantauperadilan.com,Praperadilan sebagai Lembaga Pengawas Kinerja. Theodora YSP, S.H., hlm.1, diunduh Tanggal 1 Oktober 2018, Pukul 18.45 WIB.
} 
Melihat kondisi diatas peranan Praperadilan mempunyai arti penting dalam rangka penegakan hukum Pidana di Indonesia, hal ini dikarenakan praperadilan mempunyai peran yang sangat besar yakni untuk melindungi pihak-pihak (tersangka, keluarga atau kuasanya) yang menjadi korban akibat tindakan sewenang-wenang yang dilakukan oleh aparat penegak hukum yang bersangkutan (khususnya mengenai tidak sahnya penangkapan dan penahanan). Adanya praperadilan ini membuat pihak-pihak yang menjadi korban (tersangka, keluarga atau kuasanya) tersebut diberi ruang untuk menuntut kembali hak-haknya yang dilanggar oleh aparat penegak hukum yang bersangkutan sebagaimana diatur dalam Pasal 79 KUHAP.

Praperadilan selain memberikan perlindungan dari sisi korban (tersangka), praperadilan juga berperan memberikan hak kepada penyidik, penuntut umum atau pihak ketiga yang berkepentingan untuk menuntut kejelasan terhadap haknya. Hak-hak yang dapat dituntut oleh penyidik, penuntut umum dan pihak ketiga yang berkepentingan khususnya mengenai tidak sahnya penghentian penyidikan dan penghentian penuntutan sebagaimana diatur dalam KUHAP khususnya Pasal 80.

KUHAP sebagaimana diatur dalam Pasal 95 dan 97 juga memberikan pengaturan mengenai ganti rugi dan rehabilitasi khususnya bagi seorang yang perkara pidananya dihentikan pada tingkat penyidikan atau penuntutan. Ganti rugi dan rehabilitasi dalam praperadilan pada prinsipnya adalah sebagai upaya untuk melindungi warganegara yang diduga melakukan kejahatan, tetapi ternyata tidak didukung adanya bukti-bukti yang menyakinkan sebagai akibat dari sikap dan perlakuan aparat penegak hukum yang tidak mengindahkan prinsip hakhak asasi manusia dalam melaksanakan kewenangannya. ${ }^{6}$

Melihat fakta-fakta yang ada jelas bahwa praperadilan mempunyai peranan yang besar dalam rangka penegakan hukum pidana di Indonesia. Buktinya adalah dengan adanya praperadilan, memberikan ruang kepada pihak-pihak yang dirugikan dalam proses peradilan pidana di Indonesia untuk menuntut kembali hakhaknya yang dirugikan. Ketentuan ini jelas sesuai dengan prinsip yang terkandung dalam KUHAP yang dijiwai prinsip perlindungan terhadap harkat dan martabat manusia yang juga dilindungi dalam Undang-Undang Dasar Republik Indonesia khusus Pasal 28 tentang Hak Asasi Manusia. Buktinya adalah adanya Praperadilan merupakan bagian kontrol sosial terhadap aparat penegak hukum dalam melaksanakan kewenangannya dimana tujuannya adalah untuk melindungi kepentingan individu yang dirugikan dalam rangka penegakan hukum pidana di Indonesia.

Merujuk amar Putusan Mahkamah Konstitusi Republik Indonesia Nomor 21/PUU- XII/2014 tanggal 28 April 2015, yang berbunyi antara lain : "Pasal 77 huruf a Undang-Undang Nomor 8 Tahun 1981 tentang Hukum Acara Pidana (Lembaran Negara Republik Indonesia Tahun 1981, Nomor 76, Tambahan Lembaran Negara Republik Indonesia Nomor 3209) bertentangan dengan UndangUndang Dasar Negara Republik Indonesia Tahun 1945 sepanjang tidak dimaknai termasuk penetapan

\footnotetext{
${ }^{6}$ S. Tanusubroto, Loc. Cit, hlm.2.
} 
tersangka, penggeledahan, dan penyitaan ; Pasal 77 huruf a UndangUndang Nomor 8 Tahun 1981 tentang Hukum Acara Pidana (Lembaran Negara Republik Indonesia Tahun 1981, Nomor 76, Tambahan Lembaran Negara Republik Indonesia Nomor 3209) tidak mempunyai kekuatan hukum mengikat sepanjang tidak dimaknai termasuk penetapan tersangka, penggeledahan, dan penyitaan", maka menjadi jelas dan terang bahwa penetapan tersangka dan Penyitaan menurut hukum adalah merupakan objek Praperadilan

Pemohon dilaporkan ke Polres Tulang Bawang dengan Laporan Polisi Nomor : B-1196/XI/2015/LPG/SPKT, tertanggal 08 November 2015 dengan tuduhan melakukan Tindak Pidana Korupsi Dana Program Penyediaan dan Pengembangan Sarana dan Prasarana Pertanian pada Dinas Pertanian Perkebunan dan Kehutanan Kabupaten Tulang Bawang Tahun Anggaran 2011 pada pekerjaan Perluasan Areal Cetak Sawah yang merugikan Negara sebesar Rp. 618.254.750,- (Enam ratus delapan belas juta dua ratus lima puluh empat ribu tujuh ratus lima puluh rupiah) sebagaimana dimaksud dalam Pasal 2 ayat (1) Subsider Pasal 3 Undang-Undang Nomor 31 Tahun 1999 tentang Pemberantasan Tindak Pidana Korupsi sebagaimana diubah dengan Undang-Undang Nomor 20 Tahun 2001 tentang Perubahan Atas Undang- Undang Nomor 31 Tahun 1999 tentang Pemberantasan Tindak Pidana Korupsi

Salah satu contoh permohonan pra peradilan adalah pada Putusan Perkara Nomor 3/Pid/Pra/2018/PN.Mgl, dimana pada putusan tersebut dimohonkan agar Ketua Pengadilan Negeri Menggala Cq. Hakim Tunggal
Praperadilan yang memeriksa dan mengadili permohonan ini dapat menjatuhkan putusan sebagai berikut :

Primair:

a. Menerima dan mengabulkan Permohonan Praperadilan Pemohon untuk seluruhnya;

b. Menyatakan batal demi hukum dan tidak sah penetapan Tersangka terhadap Arsam Hidayat (Pemohon) yang dikeluarkan oleh Termohon berdasarkan Surat Panggilan Nomor: SP.Gil/75/II/2018/Reskrim tertanggal $13 \quad$ Februari 2018 dengan segala akibat hukumnya;

c. Memerintahkan Termohon untuk menghentikan penyidikan terhadap Arsam Hidayat (Pemohon) berdasarkan Surat Perintah Penyidikan Nomor: Sp. Sidik/393/XI/2015/Reskrim tanggal 24 November 2015 dan Surat Perintah Penyidikan Lanjutan Nomor: $\quad$ Sp. Sidik/393A/X/2017/Reskrim tanggal 04 Oktober 2017 setelah putusan ini diucapkan;

d. Menyatakan batal demi hukum dan tidak sah Penyitaan yang dilakukan oleh Termohon terhadap Kartu Tanda Penduduk (KTP) asli milik Pemohon yakni Kartu Tanda Penduduk (KTP) NIK : 1805250908680001 atas nama Arsam Hidayat (Pemohon) beserta dokumen lainnya milik Pemohon.

e. Menghukum Termohon untuk mengembalikan Kartu Tanda Penduduk (KTP) asli milik Pemohon yakni Kartu Tanda Penduduk (KTP) NIK : 1805250908680001 atas nama Arsam Hidayat (Pemohon) beserta dokumen lainnya milik Pemohon kepada Pemohon setelah putusan ini diucapkan; 
f. Menyatakan batal dan tidak sah Penetapan Wajib Lapor yang telah dikeluarkan oleh Termohon terhadap Arsam Hidayat (Pemohon);

g. Memerintahkan Termohon untuk membebaskan status wajib lapor Arsam Hidayat (Pemohon) kepada Termohon setelah Putusan ini diucapkan;

h. Menghukum Termohon untuk membayar biaya perkara praperadilan a quo.

\section{Subsidair:}

Atau Apabila Pengadilan Negeri Menggala Cq. Hakim Tunggal Praperadilan yang memeriksa dan mengadili permohonan ini berpendapat lain, mohon putusan yang seadiladilnya (ex aequo et bono).

\section{B. Metode Penelitian}

Metode penelitian menggunakan pendekatan yuridis normatif dan empiris, pendekatan yuridis normatif dilaksanakan dengan mempelajari norma atau kaidah hukum, asas-asas hukum, sedangkan pendekatan empiris dilakukan dengan wawancara langsung terhadap narasumber yang akan berhubungan dengan masalah penelitian, analisis data yang digunakan adalah analisis kualitatif.

\section{Hasil Penelitian}

\section{Proses Penyidikan Tindak Pidana Korupsi Dana Program Penyediaan dan Pengembangan Sarana dan Prasarana Pertanian di Dinas Pertanian, Perkebunan dan Kehutanan Kabupaten Tulang Bawang}

Praperadilan menjadi hal yang menarik untuk didiskusikan oleh khalayak ramai, terutama para ahli hukum di
Indonesia. Hal ini tidak terlepas dari adanya perkembangan hukum yang terjadi dalam konteks praperadilan di dalam beberapa putusan pengadilan, yaitu masuknya pengujian sah tidaknya penetapan tersangka sebagai objek praperadilan.

Tindak pidana merupakan suatu pengertian dasar dalam Hukum Pidana. Tindak Pidana adalah pengertian yuridis, lain halnya dengan istilah perbuatan jahat atau kejahatan (crime atau verbrechen atau misdaad) yang biasa diartikan secara yuridis (hukum) atau secara kriminologis. Barda Nawawi Arief menyatakan tindak pidana secara umum dapat diartikan sebagai perbuatan yang melawan hukum baik secara formal maupun secara materiil. ${ }^{7}$

Menurut Wirjono Projodikoro, "Bahwa pengertian tindak pidana adalah suatu perbuatan yang pelakunya dapat dikenakan pidana. ${ }^{8}$ Sedangkan menurut Moeljatno, perbuatan pidana adalah suatu perbuatan yang pelakunya dapat dikenakan pidana, bagi yang melanggar perbuatan tersebut. Jadi perbuatan yang dapat dikenakan pidana dibagi menjadi 2 (dua), yakni sebagai berikut:

a. Perbuatan yang dilarang oleh undang-undang.

b. Orang yang melanggar larangan itu. ${ }^{9}$

Hasil wawancara dengan selaku Desma Yulian Jaksa Kejaksaan Negeri Menggala menyatakan bahwa fenomena praperadilan memancing reaksi yang beragam dari berbagai pihak, banyak yang memuji dgn alasan

${ }^{7}$ Barda Nawawi Arief. 1996. Bunga Rampai Kebijakan Hukum Pidana. Citra Aditya Bhakti, Bandung, hlm. 152-153.

${ }^{8}$ Wirjono Prodjodikoro, Op Cit, hlm. 65-72.

${ }^{9}$ Moeljatno. Op Cit, hlm. 2. 
bahwa hal tersebut merupakan suatu kemajuan dalam hukum acara pidana yang semakin melindungi hak asasi manusia, di sisi lain, banyak juga yang mencaci maki dnegan alasan bahwa hal tersebut sudah melanggar prinsip legalitas, dimana seharusnya hanya yang tertera di dalam Kitab Undangundang Hukum Acara Pidana (KUHAP) sajalah, yang diatur sebagai objek praperadilan, yang bisa diajukan ke acara praperadilan, sedangkan sah tidaknya penetapan tersangka tidak lah masuk ke dalam objek yang dapat diajukan ke praperadilan dalam KUHAP.

Hasil wawancara dengan Wayan Saka selaku Penasihat Hukum/Advokat menyatakan bahwa polemik pra peradilan bermula ketika Hakim Sarpin Rizaldi mengabulkan permohonan praperadilan Budi Gunawan di Pengadilan Negeri Jakarta Selatan. Saat itu, salah satu permohonan praperadilan yang diajukan dan diterima adalah mengenai sah tidaknya penetapan tersangka yang dilakukan KPK terhadap Budi Gunawan. Hakim Sarpin menerima hal tersebut dan menyatakan pada intinya bahwa penetapan tersangka adalah salah satu bentuk upaya paksa dan dapat diuji ke dalam acara praperadilan. Putusan ini pun langsung memunculkan kontroversi. Banyak pihak, baik dari aktivis hukum, aktivis lainnya, akademisi, politisi, mantan Hakim Agung, maupun Komisi Yudisial, beramai-ramai mengeluarkan statement untuk menanggapi putusan tersebut. Sekali lagi, ada yang sepakat dan banyak yang mencaci. Sebenarnya, putusan Hakim Sarpin ini bukan lah putusan pertama yang mengabulkan permohonan praperadilan atas sah tidaknya penetapan tersangka. Setidaknya, ada 1 (satu) putusan sebelum putusan Hakim Sarpin yang mengabulkan permohonan tersebut, yaitu putusan Hakim Suko Harsono dalam perkara praperadilan dnegan pemohon Bachtiar Abdul Fatah di Pengadilan Negeri Jakarta Selatan.

Hasil wawancara dengan Kisyadi selaku BPKP Perwakilan Lampung menyatakan bahwa bahwa polemik pra peradilan berlanjut ketika dalam beberapa putusan praperadilan sesudah putusan Hakim Sarpin atas permohonan pengujian sah tidaknya penetapan tersangka, hakim tidak menerima pengujian penetapan tersangka sebagai objek praperadilan. Setidaknya, ada 4 (empat) putusan yang menyatakan hal tersebut, yaitu putusan Hakim Kristanto Sahat dalam perkara praperadilan dengan pemohon Mukti Ali di Pengadilan Negeri Purwokerto, putusan Hakim Sugeng Warmanto dalam perkara parperadilan dengan pemohon DjuDju Tanuwidjaja di Pengadilan Negeri Pontianak, putusan Hakim Tati Hadiati dalam perkara praperadilan dengan pemohon Suryadharma Ali di Pengadilan Negeri Jakarta Selatan, dan putusan Hakim F. Riyadi Sunindiyo dalam perkara praperadilan dengan pemohon Suroso Atmomartoyo di Pengadilan Negeri Jakarta Selatan. Adapun 1 (satu) lagi perkara praperadilan yang menguji sah tidaknya penetapan tersangka adalah perkara yang dimohonkan oleh Sutan Bhatoegana di Pengadilan Negeri Jakarta Selatan. Namun, karena perkara pokoknya sudah masuk tahap persidangan, maka dengan mendasarkan kepada Pasal 82 Ayat (1) huruf d KUHAP, Hakim Asiadi Sembiring menyatakan bahwa permohonan tersebut gugur. Lalu, pada tanggal 28 April 2015, Mahkamah Konstitusi dalam putusannya Nomor 21/PUU-XII/2014 memutuskan 
salah satunya bahwa Pasal 77 huruf a KUHAP adalah bertentangan dengan Undang-undang Dasar NRI 1945 sepanjang tidak termasuk penetapan tersangka, penyitaan, dan penggeledahan. Artinya, dengan putusan MK ini, pengujian sah tidaknya penetapan harus termasuk dalam objek praperadilan. Beberapa waktu yang lalu, terdapat permohonan praperadilan atas sah tidaknya penetapan tersangka yang diajukan oleh Hadi Poernomo ke Pengadilan Negeri Jakarta Selatan. Hakim yang menyidangkan perkara tersebut, Haswandi, dalam amar putusannya, menyatakan bahwa sah tidaknya penetapan tersangka adalah objek yang dapat diperiksa pada tahap praperadilan.

Hasil wawancara Aris Fitria Wijaya dengan selaku Hakim Pengadilan Negeri Menggala menyatakan bahwa apabila melihat putusan-putusan mengenai apakah sah tidaknya penetapan tersangka termasuk objek praperadilan, maka kita akan mendapatkan fakta telah terjadi inkonsistensi dari Pengadilan dalam menerima hal tersebut sebagai objek praperadilan. Ada yang menerima, bahkan ada yang menolak dengan tegas. Hal ini tentu saja sangat merugikan masyarakat, terutama para pencari keadilan yang ingin menguji keabsahan penetapan tersangka nya, karena semuanya akan sangat bergantung kepada subjektifitas masing-masing hakim dan keberuntungan dari masing-masing pemohon. Kalau beruntung, maka akan mendapatkan hakim yang akan menerima pemeriksaan keabsahan penetapan tersangka dalam praperadilan. Kalau tidak beruntung, maka hakim akan menolak hal tersebut sebagai objek praperadilan. Disini kita bisa melihat bahwa tidak ada kepastian hukum megenai status keabsahan penetapan tersangka tersebut, apakah bisa diuji di praperadilan, atau tidak.

Telah ada putusan MK Nomor 21/PUU-XII/2014 yang menyatakan bahwa penetapan tersangka termasuk salah satu objek yang dapat diperiksa keabsahannya dalam praperadilan. Namun, perlu diingat, pernah ada putusan MK nomor 003/PUU-IV/2006 tertanggal 26 Juli 2006 yang pada intinya menyatakan bahwa penggunaan ajaran sifat melawan hukum materiil yang tercantum dalam penjelasan Pasal 2 ayat (1) Undang-Undang Nomor 31/1999 jo. Undang-Undang Nomor 20 Tahun 2001 tentang Pemberantasan Tindak Pidana Korupsi adalah bertentangan dengan UUD NRI 1945 dan tidak boleh dilakukan. Faktanya, dalam putusan kasasi perkara tindak pidana korupsi Nomor $2064 \mathrm{~K} / \mathrm{Pid} / 2006$ tanggal 8 Januari 2007 atas nama terdakwa H. Fahrani Suhaimi, Hakim Agung yang mengadili perkara tersebut tetap menggunakan ajaran sifat melawan hukum materiil. Fakta membuktikan bahwa ternyata hakim yang berada dalam naungan Mahkamah Agung belum tentu melaksanakan putusan MK. Hal ini menyebabkan pula adanya potensi hakim-hakim yang berada di bawah naungan MA tidak melaksanakan putusan MK terkait penetapan tersangka yang masuk ke dalam salah satu objek praperadilan.

Tidak berhenti disitu, polemik mengenai pemeriksaan sah tidaknya penetapan tersangka kemudian memasuki area hukum materiil dari praperadilan itu sendiri, yaitu apa objek yang diperiksa dalam praperadilan atas sah tidaknya penetapan tersangka. Jika berpegang secara legal formalistik, 
maka yang diperiksa dalam praperadilan atas sah tidaknya penetapan tersangka adalah syarat dari penetapan tersangka itu sendiri, yang berdasarkan Pasal 1 angka 14 KUHAP, yang berbunyi: "Tersangka adalah seorang yang karena perbuatannya atau keadaannya berdasarkan bukti permulaan patut diduga sebagai pelaku tindak pidana", adalah apakah bukti permulaan yang ada cukup berkualitas untuk digunakan sebagai dasar untuk menetapkan seseorang tersebut menjadi tersangka.

Namun, apabila dilihat dalam beberapa perkara yang menerima praperadilan atas sah tidaknya penetapan tersangka, pemeriksaan dalam perkara tersebut tidak lagi hanya menyasar kepada bukti permulaan yang ada, namun sampai kepada keabsahan dari aparat bahkan lembaga penyelidikan dan/atau penyidikannya. Misalnya, dalam perkara praperadilan Budi Gunawan. Dalam perkara tersebut, Hakim Sarpin pada dasarnya tidak memeriksa mengenai bukti permulaan yang digunakan KPK dalam menetapkan Budi Gunawan sebagai tersangka, namun memeriksa apakah KPK berwenang melakukan proses hukum terhadap Budi Gunawan dan pada akhirnya Hakim Sarpin memutuskan bahwa KPK tidak berwenang memproses Budi Gunawan secara hukum karena Budi Gunawan tidak memenuhi kualifikasi pihak-pihak yang dapat diproses hukum oleh KPK berdasarkan Pasal 11 UU 30/2002 tentang KPK, yaitu aparat penegak hukum atau penyelenggara Negara, mendapat perhatian yang meresahkan masyarakat, dan melibatkan. kerugian Negara paling sedikit Rp. 1.000.000.000,- (satu milyar rupiah), sehingga seluruh proses hukum yang dilakukan KPK dianggap tidak sah,

termasuk penetapan tersangka yang dilakukan KPK terhadap Budi Gunawan.

Dalam perkara yang lain, yaitu atas pemohon Hadi Poernomo, Hakim Haswandi juga pada dasarnya tidak memeriksa bukti permulaan yang ada untuk membuktikan sah tidaknya penetapan tersangka yang dilakukan KPK. Hakim pada saat itu membuktikan bahwa penyelidik dan penyidik yang melakukan proses hukum terhadap Hadi Poernomo adalah penyelidik dan penyidik independen, yang mana menurut hakim, penyelidik dan penyidik independen adalah tidak sah keberadaannya, sehingga seluruh proses hukum yang dilakukan oleh penyelidik dan penyidik independen juga harus dianggap tidak sah, termasuk penetapan tersangka nya, sehingga penetapan tersangka yang dilakukan harus lah dibatalkan. Hakim pada saat itu mendasarkan kepada ketentuan Pasal 39 ayat (3) UndangUndang Nomor 30 Tahun 2002, yang berbunyi: Penyelidik, penyidik, dan penuntut umum yang menjadi pegawai pada Komisi Pemberantasan Korupsi, diberhentikan sementara dari instansi kepolisian dan kejaksaan selama menjadi pegawai pada Komisi Pemberantasan Korupsi.

Apabila dicermati lebih lanjutsebenarnya yang diuji oleh pemohon-pemohon dan yang diperiksa oleh para hakim di atas, bukan lah atas sah tidaknya penetapan tersangka, namun sudah masuk menguji sah tidaknya penyelidikan dan/atau penyidikan. Pemeriksaan atas permohonan-permohonan di atas adalah pemeriksaan mengenai keabsahan dari lembaga dan/atau aparat yang melakukan penyelidikan dan/atau penyidikan, bukan mengenai bukti 
permulaan yang ada untuk menetapkan pemohon-pemohon di atas sebagai tersangka. Hal inilah yang juga kemudian memunculkan kritik dari berbagai pihak yang pada intinya menyatakan bahwa seharusnya hakim tidak menyentuh sampai kepada pemeriksaan keabsahan dari lembaga dan/atau aparat yang melakukan penyelidikan dan/atau penyidikan, melainkan hanya membuktikan bahwa apakah penetapan tersangka yang dilakukan sudah berdasarkan bukti permulaan atau belum.

Berdasarkan pemaparan di atas, diketahui bahwa setidaknya ada 2 (dua) permasalahan yang ada dalam praperadilan di Indonesia hari ini, yang mana permasalahan-permasalahan tersebut harus segara dijawab agar tercipta suatu kepastian hukum yang melindungi masyarakat, yaitu:

a. Ketidakjelasan apakah sebenarnya pengujian keabsahan sah tidaknya penetapan tersangka masuk sebagai objek praperadilan.

b. Ketidakjelasan mengenai apa sebenarnya objek yang diperiksa dalam pemeriksaan sah tidaknya penetapan tersangka, apakah seharusnya sebatas bukti permulaan, atau sampai kepada keabsahan penyelidik dan/atau penyidikan yang melakukan penyelidikan dan/atau penyidikan.

Seharusnya penetapan tersangka masuk sebagai salah satu objek praperadilan. Pada dasarnya, objek pemeriksaan keabsahan penetapan tersangka seharusnya hanyalah bukti permulaan yang harus dibuktikan kualitasnya apakah cukup untuk menetapkan sebagai seorang tersangka. Namun, bukan berarti pemeriksaan atas keabsahan penyelidik dan/atau penyidik yang melakukan proses penyelidikan dan/atau penyidikan tidak dapat dilakukan. Penulis berpendapat bahwa pemeriksaan atas keabsahan penyelidik dan/atau penyidik yang melakukan proses penyelidikan dan/atau penyidikan, yang menurut penulis lebih tepat dikatakan sebagai pengujian keabsahan penyelidikan dan/atau penyidikan, dapat dilakukan pula pada tahap praperadilan dan dengan pertimbangan menyederhanakan perkara, dapat dilakukan pada persidangan praperadilan yang sama dengan permohonan pokok, misalnya keabsahan penetapan tersangka. Penulis hanya ingin menggambarkan bahwa pada intinya, keabsahan penyelidikan dan/atau penyidikan adalah berbeda dengan keabsahan penetapan tersangka dan hanya memiliki hubungan langsung apabila penyelidikan dan/atau penyidikan dinyatakan tidak sah, maka penetapan tersangka yang dilakukan menjadi tidak sah pula. Apabila penyelidikan dan/atau penyidikan dinyatakan sah, maka tidak serta merta penetapan tersangka menjadi sah pula dan harus tetap dibuktikan apakah bukti permulaan yang ada dapat digunakan untuk menetapkan orang tersebut menjadi tersangka untuk dapat menyatakan bahwa penetapan tersangka yang dilakukan adalah sah. Jadi, inti objek pemeriksaan dari keabsahan penetapan tersangka harus lah tetap kualitas bukti permulaan yang digunakan sebagai dasar penetapan tersangka.

Tidak jelasnya pengaturan mengenai praperadilan di Indonesia, khususnya mengenai pengujian keabsahan penetapan tersangka, dan betapa inkonsistennya putusan para hakim yang mengadili pengujian keabsahan penetapan tersangka. Hal ini jelas 
berakibat kepada tidak adanya kepastian hukum mengenai aturan pengujian keabsahan penetapan tersangka, yang mana hal tersebut bisa saja merugikan masyarakat, terutama para pencari keadilan. Bisa dibilang "usia" pengujian keabsahan penetapan tersangka masih lah seumur jagung, namun permasalahan yang ditimbulkan berupa ketidakjelasan dari pengujian ini sudah bermunculan. Kalau tidak segera direspon dengan diberikan pengaturan yang jelas, maka masalahmasalah yang ada saat ini tidak akan kunjung selesai, akan berpotensi menimbulkan masalah-masalah lainnya di kemudian hari, dan, bisa jadi, akan tetap terjadi inkonsistensi putusan dari para hakim mengenai pengujian keabsahan penetapan tersangka.

Ada 2 (dua) pihak yang harusnya merespon hal ini. Yang pertama, harusnya masalah ini direspon oleh Mahkamah Agung (MA) dengan menjalankan fungsinya sebagai penjaga kesatuan hukum dalam institusi pengadilan. Ketidakjelasan pengaturan tentang pengujian keabsahan penetapan tersangka telah menyebabkan inkonsistensi putusan dari para hakim di bawah naungan MA, sehingga seharusnya MA merespon hal ini agar inkonsistensi putusan hakim yang berada di bawah naungannya tidak terjadi. MA memandang belum perlu untuk mengeluarkan baik dalam bentuk Peraturan MA maupun surat edaran mengenai aturan hukum acara praperadilan, termasuk pengujian keabsahan penetapan tersangka. Putusan MK No. 21/PUU-XII/2014 terkait tafsir bukti permulaan yang cukup dan perluasan objek praperadilan sudah cukup jelas dimana objek praperadilan hanya tinggal menambahkan penetapan tersangka, penggeledahan, dan penyitaan.
Masih ada yang tidak diatur dalam putusan MK (memang putusan MK juga tidak akan bisa mengatur hal ini) dan harus diatur lebih lanjut pada tataran teknis, yaitu hukum acara praperadilan itu sendiri, termasuk pengujian keabsahan penetapan tersangka, mulai dari objek pemeriksaan, teknis pemeriksaan, sampai pada beban pembuktian (burden of proof) dari objek pemeriksaan itu sendiri. Seharusnya, dalam hal ini, MA mengambil peran untuk memberikan pedoman dan panduan yang dapat digunakan para hakim di bawah naungannya agar terjadi kesatuan hukum dalam melaksanakan pemeriksaan perkara praperadilan, khususnya mengenai pengujian keabsahan penetapan tersangka, sehingga inkonsistensi putusan hakim dapat tidak terjadi lagi.

Sebenarnya, untuk semua materi praperadilan yang tercantum dalam Pasal 77 KUHAP sebelum adanya putusan MK mengenai perluasan objek praperadilan di atas, baik untuk pengujian sah tidaknya penangkapan, penahanan, pengehentian penyidikan, maupun penghentian penuntutan, Indonesia, khususnya MA, belum memiliki aturan yang jelas mengenai objek pemeriksaan, teknis pemeriksaan, dan juga beban pembuktian dari objek pemeriksaan itu sendiri. Semuanya diserahkan kepada praktik, yang apabila ditanyakan kepada para hakim se-Indonesia, penulis sedikit banyak yakin mereka tidak tahu mengapa sejarahnya seperti itu, mengapa diambil keputusan seperti itu, apa logikanya dan apa dasar hukumnya. Namun, penulis disini tidak akan membahas mengenai hal tersebut lebih lanjut karena penulis ingin memfokuskan pembahasan khusus kepada pengujian keabsahan penetapan 
tersangka sebagai objek praperadilan, bukan objek-objek praperadilan yang sudah diatur secara jelas di KUHAP.

Apa yang seharusnya dilakukan MA sebagai bentuk respon atas ketidakjelasan hukum acara praperadilan, khususnya mengenai pengujian keabsahan penetapan tersangka? Sebelumnya, penulis ingin menjelaskan bahwa pada dasarnya, pelaksanaan fungsi Mahkamah Agung sebagai penjaga kesatuan hukum melekat pada fungsi Judex Juris, yang dimiliki Mahkamah Agung pada tahap kasasi, dimana pada tahap tersebut, Mahkamah Agung bisa melakukan koreksi mengenai aspek hukum suatu putusan yang dianggap kurang tepat dan kemudian memberikan panduan dan arahan aspek hukum yang tepat, yang kemudian dapat diikuti oleh hakim-hakim pada tingkat pertama (Hakim Pengadilan Negeri). Namun, berdasarkan Pasal 45A ayat (2) huruf b Undang-Undang Nomor 5 Tahun 2004 tentang Perubahan Undang-Undang Nomor 14 Tahun 1985 tentang Mahkamah Agung, putusan praperadilan tidak dapat diajukan ke tahap kasasi, sehingga Mahkamah Agung tidak dapat menjalankan fungsi penjaga kesatuan hukum melalui Judex Juris.

Sebenarnya MA pernah melakukan penjagaan kesatuan hukum tentang praperadilan, setidaknya 2 (dua) kali, yang dilakukan pada tahap Peninjauan Kembali (PK). Pengujian pada tahap PK terjadi karena pasca diundangkannya KUHAP pada tahun 1981 dan keluarnya perubahan UU Mahkamah Agung terakhir tahun 2009, tidak ada aturan mengenai PK atas putusan praperadilan. Pertama, hal tersebut terjadi pada tahun 2011, pada perkara PK atas praperadilan keabsahan penghentian penuntutan oleh Kejaksaan atas Bibit Samad Riyanto dan Chandra M. Hamzah. Majelis Hakim yang pada saat itu diketuai oleh Ketua Mahkamah Agung saat itu, Harifin Tumpa, menyatakan bahwa putusan praperadilan tidak dapat diajukan upaya hukum peninjauan kembali. Alasannya cukup sederhana, yaitu karena putusan praperadilan tidak dapat diajukan upaya hukum biasa, yaitu banding dan kasasi (Pasal 83 Ayat (1) KUHAP dan Pasal 45A Ayat (2) huruf a UU 5/2004), maka putusan praperadilan juga tidak dapat diajukan upaya hukum luar biasa, yaitu Peninjauan Kembali.

Kedua, terjadi pada tahun 2013, dimana dalam perkara PK nomor 87 PK/Pid.B/2013, Majelis Hakim yang diketuai Hakim Syarifudin, menyatakan bahwa putusan praperadilan dapat diajukan PK dengan syarat bahwa Hakim pada tingkat pertama telah melakukan penyelundupan hukum, yaitu yaitu praperadilan yang melampaui kewenangannya sesuai pasal 77 KUHAP. Putusan ini pun akhirnya menjadi salah satu hasil Rapat Pleno Kamar Pidana Mahkamah Agung, yang dilakukan pada tanggal 19-20 Desember 2013 di Pusdiklat Mahkamah Agung RI, yang kemudian dikuatkan dengan pemberlakuan aturan ini melalui SEMA 4 Tahun 2014, yang artinya, aturan ini berlaku dan mengikat seluruh hakim di bawah naungan Mahkamah Agung.

Pada tahap PK, Hakim yang memeriksa tidak lagi berfokus kepada aspek hukumnya, namun kepada fakta-fakta yang ada di persidangan tingkat pertama, atau dengan kata lain, sebenarnya, PK bersifat Judex Facti, tidak seperti pada tahap kasasi 
dimana Hakim tidak lagi memeriksa fakta, melainkan fokus kepada aspek hukumnya, atau dengan kata lain sebagai Judex Juris. Seharusnya, pelaksanaan fungsi menjaga kesatuan hukum memang hanya dilakukan pada tahap kasasi. Namun, sangat disayangkan, Undang-Undang Mahkamah Agung sendirilah yang membatasi hal tersebut terjadi.

Hal yang terpenting ada pelaksanaan fungsi tersebut dari Mahkamah Agung, walaupun dilakukan pada tahap PK, yang mana sebenarnya hal tersebut salah secara kodrati, pelaksanaan fungsi tersebut pada tahap PK juga tidak akan berjalan dengan baik. Hal ini dikarenakan, yang harus dipahami adalah, Mahkamah Agung tidak akan pernah bisa menyelenggarakan persidangan PK tersebut dengan inisiatif sendiri, melainkan harus berdasarkan adanya pengajuan PK oleh pihak-pihak yang bersengketa dalam kasus tersebut. Tanpa adanya pengajuan PK atas putusan praperadilan, maka tidak akan pernah ada persidangan PK, sehingga fungsi penjagaan kesatuan hukum MA melalui putusan PK pun tidak dapat dilakukan secara maksimal.

Sebenarnya, ada satu instrumen yang dapat dilakukan tanpa harus menunggu ada pengajuan PK oleh pihak-pihak yang bersengkata dalam perkara tersebut, yaitu Kasasi Demi Kepentingan Hukum (KDKH), yang dapat diajukan oleh Jaksa Agung, berdasarkan Pasal 259-262 KUHAP, yang mana, menurut peneliti dari Lembaga Kajian dan Advokasi Independensi Peradilan (LeIP), Arsil, dalam tulisannya yang berjudul "Penunjang Fungsi Mahkamah Agung Yang Terlupakan", merupakan salah satu instrumen yang dapat mendukung fungsi Mahkamah Agung sebagai penjaga kesatuan hukum. Namun, dalam tulisan tersebut juga disebutkan pula bahwa pada faktanya, dengan berbagai faktor, KDKH saat ini hampir tidak pernah dilakukan, sehingga pelaksanaan fungsi menjaga kesatuan hukum melalui instrumen ini dikhawatirkan juga tidak akan berhasil.

Tanpa disadari, Mahkamah Agung pernah melakukan hal tersebut dengan mengeluarkan Surat Edaran Mahkamah Agung (SEMA), yaitu SEMA 7 Tahun 2014 mengenai Pengajuan Permohonan Kembali Dalam Perkara Pidana, yang mengatur mengenai pembatasan pengajuan PK dalam pekara pidana yang hanya dapat dilakukan 1 (satu) kali. Perlu diketahui, bahwa SEMA ini lahir sebagai jawaban dari MA terkait putusan MK nomor 34/PUU-XI/2013 yang memperbolehkan pengajuan $\mathrm{PK}$ lebih dari 1 (satu) kali. SEMA ini berisi tentang petunjuk bagi para hakim di bawah naungan MA mengenai sikap MA sebagai institusi terhadap putusan MK tersebut, yang pada intinya MA mengenyampingkan putusan tersebut dan menyatakan bahwa pengajuan PK dalam perkara pidana hanya dapat dilakukan 1 (satu) kali.

SEMA merupakan upaya MA dalam menjalankan fungsi menjaga kesatuan hukum, yaitu menyatukan pandangan para hakim di bawah naungan MA bahwa PK dalam perkara pidana hanya dapat dilakukan 1 (satu).

Berdasarkan Putusan MK nomor 21/PUU-XII/2014, serta merumuskan hukum acaranya secara jelas, rinci, dan tegas. Pilihan lain adalah dengan cara memasukkan pengaturan-pengaturan ini ke dalam RKUHAP dan segera mengesahkan RKUHAP tersebut. Hal ini juga tidak terlepas dari sebagian 
besar pola pikir hakim Indonesia, yang menurut penulis, lebih patuh dan merasa terikat kepada aturan tertulis yang ada di peraturan seperti Undangundang atau setingkatnya, daripada aturan internal seperti SEMA, sehingga seharusnya aturan ini diatur dalam peraturan berbentuk Undang-undang atau setingkatnya.

Pada dasarnya, keabsahan penetapan tersangka sebagai objek praperadilan harus secepatnya direspon dengan memberikan pengaturan yang jelas, tegas, dan rinci, sebelum semakin banyak masalah yang bermunculan dari praperadilan tersebut. Pengaturan yang harus ada mengenai prapedilan atas keabsahan penetapan tersangka setidaknya harus mencakup:

a. Kejelasan apakah keabsahan penetapan tersangka dapat menjadi salah satu objek praperadilan.

b. Kejelasan mengenai objek pemeriksaan dalam praperadilan tersebut apabila diterima sebagai salah satu objek praperadilan, apakah hanya sampai pemeriksaan bukti permulaan yang menjadi dasar penetapan tersangka, atau sampai kepada keabsahan lembaga dan/atau aparat yang melakukan proses penyelidikan dan/atau penyidikan.

c. Mekanisme beracara dalam praperadilan itu sendiri, mulai dari tahapan pemeriksaan, teknis pemeriksaan, sampai kepada siapa harus dibebankan beban pembuktian (burden of proof) dalam perkara tersebut. Apakah karena praperadilan secara praktik mengikuti hukum acara perdata, sehingga beban pembuktian mengacu kepada Pasal 163 H.I.R, dimana "siapa yang mendalilkan, ia yang harus membuktikan", yang artinya beban pembuktian ada di tangan Pemohon praperadilan, atau seharusnya Termohon lah yang seharusnya diberikan beban pembuktian untuk menunjukkan kualitas bukti permulaan yang mereka miliki untuk menetapkan Pemohon sebagai tersangka.

Selain itu, MA dan legislatur sudah harus mulai memikirkan untuk membuka jalan pengajuan kasasi atas putusan praperadilan, karena terbukti bahwa penutupan jalan kasasi terhadap putusan praperadilan seperti saat ini ternyata menimbulkan suatu dampak hukum berupa MA tidak dapat melakukan koreksi terhadap aspek hukum suatu putusan praperadilan, yang artinya menghambat MA untuk melaksanakan fungsinya sebagai penjaga kesatuan hukum di institusi Pengadilan. Namun, mengingat pembahasan revisi KUHAP ataupun RKUHAP yang hampir bisa dipastikan memakan waktu yang lama, sedangkan mengingat kebutuhan, menurut penulis, sangat mendesak adanya pengaturan yang jelas mengenai pengujian keabsahan penetapan tersangka, dalam waktu dekat, MA segera mengeluarkan SEMA yang mengatur tentang hal ini agar tercipta suatu keseragaman dan kesatuan putusan-putusan dari hakim yang mengadili perkara pengujian keabsahan penetapan tersangka dalam tahap praperadilan dan inkonsistensi putusan pun akan dapat dihindari, sehingga masyarakat pun akan dapat menikmati kepastian hukum dari proses praperadilan tersebut.

Hasil amandemen kedua UUD NRI 1945 menghasilkan Pasal 28D ayat (1) UUD NRI 1945 yang berbunyi "Setiap orang berhak atas pengakuan, jaminan, perlindungan, dan kepastian hukum yang adil serta perlakuan yang sama dihadapan hukum". Untuk memenuhi hak konstitusional warga 
Negara tersebut, dalam permasalahan ini, harus segera ada respon, baik dari MA, maupun dari legislatur, atau dari siapapun, mengenai pengaturan yang jelas, tegas, dan rinci mengenai pengujian keabsahan penetapan tersangka pada proses praperadilan. Janganlah jadikan ketidakjelasan yang ada saat ini menjadi ajang perjudian hukum bagi masyarakat, yang di(ter)biarkan (sengaja yang tidak sengaja) oleh MA dan legislatur, dalam arti, MA dan legislatur sengaja membiarkan ketidakjelasan pengaturan mengenai praperadilan atas keabsahan penetapan tersangka, yang mana sejatinya, MA dan legislatur secara tidak sadar membiarkan masyarakat kebingungan mencari kepastian hukum dan berjudi dengan hukum dari proses peradilan yang ada tentang pengujian keabsahan penetapan tersangka saat ini. Mari berikan hak konstitusional warga Negara untuk mendapatkan kepastian hukum dengan membuat aturan yang jelas dan tegas tentang pengujian keabsahan penetapan tersangka pada tahap praperadilan.

Proses penyidikan tindak pidana korupsi terhadap tersangka yang dilakukan terhadap dikabulkannya penetapan tersangka dalam Perkara Nomor 3/Pid/Pra/2018/PN.Mgl oleh penyidik diputuskan bahwa

a. Mengabulkan Permohonan Pemohon Praperadilan untuk seluruhnya.

b. Menyatakan Surat Perintah Penyidikan

Nomor Sp.Sidik/116/IV/2017/Subd it III/Dirkrimsus tertanggal 17 April 2017 perkara tindak Pidana Korupsi pengembangan sarana dan prasarana pertanian di Dinas Pertanian, Perkebunan dan Kehutanan Kabupaten Tulang Bawang, Sebagaimana dimaksud dalam Pasal 2 dan Pasal 3 Undangundang Nomor 31 Tahun 1999 Jo Undang-Undang Nomor 20 Tahun 2001 tentang Perubahan Atas Undang-Undang Nomor 31 Tahun 1999 tentang Pemberantasan Tindak Pidana Korupsi Jo Pasal 55 ayat (1) Ke-1 KUHP, Pasal 56 ayat (1) KUHPidana adalah tidak sah dan tidak berdasar atas hukum, dan oleh karenanya Penetapan/Surat Perintah Penyidikan a quo tidak mempunyai kekuatan Hukum yang mengikat.

c. Menyatakan penetapan tersangka atas diri pemohon yang dilakukan oleh termohon dalam perkara tindak pidana korupsi dana program penyediaan dan pengembangan sarana dan prasarana pertanian di Dinas Pertanian, Perkebunan dan Kehutanan Kabupaten Tulang Bawang Penetapan a quo tidak mempunyai kekuatan Hukum yang mengikat.

d. Menyatakan tidak sah segala keputusan atau penetapan yang dikeluarkan lebih lanjut oleh termohon yang berkaitan dengan penetapan tersangka terhadap diri pemohon oleh termohon.

e. Membebankan biaya perkara yang timbul kepada Negara.

f. Membebankan biaya perkara yang timbul kepada Negara.

Berdasarkan uraian di atas, maka dapat dianalisis proses penyidikan tindak pidana korupsi dana program penyediaan dan pengembangan sarana dan prasarana pertanian di Dinas Pertanian, Perkebunan dan Kehutanan Kabupaten Tulang Bawang sudah sesuai dengan ketentuan yang ada di dalam Kitab Undang-Undang Hukum Acara Pidana, khususnya Pasal 77 KUHAP yang mengatur objek Praperadilan, dimana Pengadilan 
Negeri Menggala $C q$. Hakim Tunggal Praperadilan yang memeriksa dan mengadili permohonan ini berpendapat lain, mohon putusan yang seadiladilnya (ex aequo et bono).

\section{Kewenangan Mengadili oleh} Hakim Pra Peradilan tentang Penetapan Seseorang Menjadi Tersangka dalam Perkara Tindak Pidana Korupsi Dana Program Penyediaan dan Pengembangan Sarana dan Prasarana Pertanian Pasca Putusan MK Nomor 21/PUUXII/2014 Berdasarkan Putusan Perkara 3/Pid/Pra/2018/PN.Mgl.

Kodifikasi peraturan di Indonesia tercermin salah satunya pada Kitab Undang-Undang Hukum Pidana. Pasal 1 ayat (1) Kitab UndangUndang Hukum Pidana selalu menjadi hal paling utama dalam pelaksanaan menjalankan peraturan perundangundangan. Pasal 1 ayat (1) berbunyi tiada suatu perbuatan yang boleh dihukum, melainkan atas kekuatan aturan pidana dalam undang-undang, yang terdahulu dari perbuatan itu.

Praperadilan hanya suatu lembaga baru yang ciri dan eksistensinya.

a) Berada dan merupakan kesatuan yang melekat pada tingkat Pengadilan Negeri, dan sebagai lembaga pengadilan, hanya dijumpai pada tingkat Pengadilan Negeri sebagai satuan tugas yang tidak terpisah dari Pengadilan Negeri,

b) Dengan demikian, Praperaddilan bukan berada di luar atau samping maupun sejajar dengan Pengadilan Negeri, tapi hanya merupakan divisi dari Pengadilan Negeri, c) Administrative yustisial, personil, peralatan, dan finansial bersatu dengan Pengadial Negeri, dan berada di bawah pimpinan serta pengawasan dan pembiaan Ketua Pengadilan Neger,

d) Tata laksana fungsi yustisialnya merupakan bagaian dari fungsi yustisial Pengadilan Negeri itu sendiri. $^{10}$

Hasil wawancara dengan selaku Desma Yulian Jaksa Kejaksaan Negeri Menggala menyatakan bahwa Pasal 1 ayat 1 Kitab Undang-Undang Hukum Pidana memuat azas legalitas yang tercakup dalam rumus yaitu tiada delik, tiada hukuman tanpa suatu peraturan yang terlebih dahulu menyebut perbuatan yang bersangkutan sebagai suatu delik dan yang memuat suatu hukuman yang dapat dijatuhkan atas delik itu.

Hasil wawancara dengan Wayan Saka selaku Penasihat Hukum/Advokat menyatakan bahwa berdasarkan unsurnya, hukum pidana dibagi menjadi hukum pidana subyetif (ius puniendi) dan Hukum Pidana Obyektif (Ius Puinale). Hukum Pidana Subyektif melingkupi aturan yang mengatur hak negara atau perlengkapan negara untuk menghukum dan menyelesaikan tindak pidana (delict) berdasarkan Hukum Pidana Obyektif. Hukum Pidana Obyektif merupakan aturan yang memuat keharusan, larangan dan pelanggaran yang mengakibatkan dikenakannya hukuman atau sanksi. Hukum Pidana Obyektif kemudian dibagi menjadi Hukum Pidana Materil (material strafrecht) seperti Kitab Undang-Undang Hukum Pidana dan Hukum Pidana Formil (formeel strafhtrecht/strafprocesrecht) yang

${ }^{10}$ M.Yahya Harahap, Hukum Acara Perdata, Sinar Grafika, Jakarta,.2012, hlm 1 
tercipta dalam bentuk UndangUndang Nomor 8 Tahun 1981 Tentang Hukum Acara Pidana (selanjutnya disebut Kitab UndangUndang Hukum Acara Pidana).

Hasil wawancara dengan Kisyadi selaku BPKP Perwakilan Lampung menyatakan bahwa bahwa Kitab Undang-Undang Hukum Acara Pidana diberlakukan mulai tanggal 1981 menggantikan Het Herziene Inlands Reglement (Staatblad Tahun 1941 Nomor 44) dan Undang-Undang Nomor 1 Drt. Tahun 1951 (Lembaran Negara Tahun 1951 Nomor 9, Tambahan Lembaran Negara Nomor 81) dengan tujuan penegakkan hukum dan perlindungan Hak Asasi Manusia.

Pertimbangan hakim merupakan salah satu aspek terpenting dalam menentukan terwujudnya nilai dari suatu putusan hakim yang mengandung keadilan (ex aequo et bono) dan mengandung kepastian hukum, di samping itu juga mengandung manfaat bagi para pihak yang bersangkutan sehingga pertimbangan hakim ini harus disikapi dengan teliti, baik, dan cermat. Apabila pertimbangan hakim tidak teliti, baik, dan cermat, maka putusan hakim yang berasal dari pertimbangan hakim tersebut akan dibatalkan oleh Pengadilan Agung. ${ }^{11}$

Hakim dalam pemeriksaan suatu perkara juga memerlukan adanya pembuktian, dimana hasil dari pembuktian itu akan digunakan sebagai bahan pertimbangan dalam memutus perkara. Pembuktian merupakan tahap yang paling penting dalam pemeriksaan

11 Mukti Arto. 2016. Praktek Perkara Perdata pada Pengadilan Agama. Pustaka Pelajar. Yogyakarta, hlm.140. di persidangan. Pembuktian bertujuan untuk memperoleh kepastian bahwa suatu peristiwa/fakta yang diajukan itu benar-benar terjadi, guna mendapatkan putusan hakim yang benar dan adil. Hakim tidak dapat menjatuhkan suatu putusan sebelum nyata baginya bahwa peristiwa/fakta tersebut benar-benar terjadi, yakni dibuktikan kebenaranya, sehingga nampak adanya hubungan hukum antara para pihak. ${ }^{12}$

Selain itu, pada hakikatnya pertimbangan hakim hendaknya juga memuat tentang hal-hal sebagai berikut

a. Pokok persoalan dan hal-hal yang diakui atau dalil-dalil yang tidak disangkal.

b. Adanya analisis secara yuridis terhadap putusan segala aspek menyangkut semua fakta/hal-hal yang terbukti dalam persidangan.

c. Adanya semua bagian dari petitum Penggugat harus dipertimbangkan/ diadili secara satu demi satu sehingga hakim dapat menarik kesimpulan tentang terbukti/tidaknya dan dapat dikabulkan/ tidaknya tuntutan tersebut dalam amar putusan. ${ }^{13}$

Hasil wawancara Aris Fitria Wijaya dengan selaku Hakim Pengadilan Negeri Menggala menyatakan bahwa salah satu perlindungan Hak Asasi Manusia dalam Kitab Undang-Undang Hukum Acara Pidana tercermin dengan adanya Praperadilan yang memiliki tujuan sebagaimana tertuang dalam penjelasan Pasal 80 Kitab UndangUndang Hukum Acara Pidana yaitu untuk menegakkan hukum, keadilan, kebenaran melakui sarana pengawasan horizontal.

\footnotetext{
${ }^{12}$ Ibid, hlm. 141.

${ }^{13}$ Ibid, hlm. 142.
} 
Teori pembuktian berdasarkan undangundang secara negatif (Negatief Wettelijke Bewijs Theorie) HIR maupun KUHAP, begitu pula Ned. Sv. Yang lama dan yang baru, semuanya menganut sistem atau teori pembuktian berdasarkan undang-undang negatif. Pasal 183 KUHAP mengatur bahwa "Hakim tidak boleh menjatuhkan pidana kepada seorang, kecuali apabila dengan sekurang-kurangnya dua alat bukti yang sah ia memperoleh keyakinan bahwa suatu tindak pidana benar- benar terjadi dan bahwa terdakwalah yang bersalah melakukannya." Pasal 185 ayat (2) KUHAP mengatakan bahwa keterangan seorang saksi saja tidaklah cukup untuk menganggap kesalahan terdakwa telah terbukti. Ini disebut bukti minimum. Penjelasan Pasal 183 KUHAP mengatakan bahwa ketentuan ini adalah untuk menjamin tegaknya kebenaran, keadilan, dan kepastian hukum bagi seorang. Berdasarkan undang-undang pengakuan terhadap teori pembuktian hanya berlaku untuk keuntungan terdakwa, tidak dimaksudkan untuk menjurus kepada dipidananya orang yang tidak bersalah hanya dapat kadang-kadang memaksa dibebaskannya orang bersalah. ${ }^{14}$

Berdasarkan uraian di atas, maka dapat dianalisis kewenangan mengadili oleh Hakim Pra Peradilan tentang penetapan seseorang menjadi tersangka dalam perkara tindak pidana korupsi dana program penyediaan dan pengembangan sarana dan prasarana pertanian pasca Putusan MK Nomor 21/PUU-XII/2014 berdasarkan Putusan Perkara Nomor 3/Pid/Pra/2018/PN.Mgl adalah Hakim telah mempertimbangkan bahwa Pengadilan Negeri Menggala $C q$. Hakim Tunggal

\footnotetext{
${ }^{14}$ Andi Hamzah, Hukum Acara Pidana. Sinar Grafika, Jakarta, 2001, hlm. 247-253
}

Praperadilan yang memeriksa dan mengadili permohonan ini berpendapat lain, mohon putusan yang seadiladilnya (ex aequo et bono).

\section{Akibat Hukum Putusan Pra Peradilan Terhadap Penetapan Seseorang Menjadi Tersangka dalam Perkara Tindak Pidana Korupsi Dana Program Penyediaan dan Pengembangan Sarana dan Prasarana Pertanian Berdasarkan Putusan Perkara Nomor 3/Pid/Pra/2018/PN.Mgl.}

Hasil wawancara dengan selaku Desma Yulian Jaksa Kejaksaan Negeri Menggala menyatakan bahwa Kitab Undang-Undang Hukum Acara Pidana diberlakukan mulai tanggal 1981 menggantikan Het Herziene Inlands Reglement (Staatblad Tahun 1941 Nomor 44) dan Undang-Undang Nomor 1 Drt. Tahun 1951 (Lembaran Negara Tahun 1951 Nomor 9, Tambahan Lembaran Negara Nomor 81) dengan tujuan penegakkan hukum dan perlindungan Hak Asasi Manusia. Salah satu perlindungan Hak Asasi Manusia dalam Kitab UndangUndang Hukum Acara Pidana tercermin dengan adanya Praperadilan yang memiliki tujuan sebagaimana tertuang dalam penjelasan Pasal 80 Kitab Undang-Undang Hukum Acara Pidana yaitu untuk menegakkan hukum, keadilan, kebenaran melakui sarana pengawasan horizontal.

Radbruch mengatakan bahwa hukum itu harus memenuhi berbagai karya disebut sebagai nilai dasar dari hukum. Nilai dasar hukum tersebut adalah: keadilan, kegunaan dan kepastian hukum.. ${ }^{15}$ Sekalipun ketiga-tiganya itu merupakan nilai dasar dari hukum,

15 Satjipto Rahardjo, "Ilmu Hukum", (Bandung : Alumni, 1986), hlm. 21. 
namun di antara mereka terdapat suatu Spannungsverhaltnis (ketegangan), oleh karena di antara ketiga nilai dasar hukum tersebut masing-masing mempunyai tuntutan yang berbeda satu sama lainnya, sehingga ketiganya mempunyai potensi untuk saling bertentangan. ${ }^{16}$

Hasil wawancara dengan Wayan Saka selaku Penasihat Hukum/Advokat menyatakan bahwa praperadilan sebagai upaya pengawasan penggunaan wewenang dalam menjamin perlindungan Hak Asasi Manusia, tertuang secara eksplisit dalam Konsideran Menimbang huruf (a) dan huruf (c) Kitab Undang-Undang Hukum Acara Pidana yang berbunyi:

a) Bahwa negara Republik Indonesia adalah negara hukum berdasarkan Pancasila dan Undang-Undang Dasar 1945 yang menjunjung tinggi hak asasi manusia serta yang menjamin segala warganegara bersamaan kedudukannya di dalam hukum dan pemerintahan dan wajib menjunjung hukum dan pemerintahan itu dengan tidak ada kecualinya.

c) bahwa pembangunan hukum nasional yang demikian itu di bidang hukum acara pidana adalah agar masyarakat menghayati hak dan kewajibannya dan untuk meningkatkan pembinaan sikap para palaksana penegak hukum sesuai dengan fungsi dan wewenang masing-masing ke arah tegaknya hukum, keadilan dan perlindungan terhadap harkat dan martabat manusia, ketertiban serta kepastian hukum demi terselenggaranya negara hukum

${ }^{16}$ E. Utrecht, Pengantar Dalam Hukum Indonesia, Balai Buku Ichtiar, Jakarta 1962, hlm. 24-28. sesuai dengan Undang- Undang Dasar 1945.

Tugas Praperadilan sebagaimana dalam ketentuan Pasal 79, Pasal 80, Pasal 81 Kitab Undang-Undang Hukum Acara Pidana meliputi tiga pokok sebagai berikut: Tugas Praperadilan sebagaimana dalam ketentuan Pasal 79, Pasal 80, Pasal 81 Kitab Undang-Undang Hukum Acara Pidana meliputi tiga pokok sebagai berikut:

a. Permintaan pemeriksaan tentang sah atau tidaknya suatu penangkapan atau penahanan yang diajukan oleh tersangka, keluarga dan kuasanya kepada ketua pengadilan negeri dengan menyebutkan alasannya.

b. Permintaan untuk memeriksa sah atau tidaknya suatu penghentian penyidikan, atau penuntutan, dapat diajukan oleh penyidik atau penuntut umum, pihak ketiga yang berkepentingan kepada ketua pengadilan negeri dengan meynebutkan alasannya.

c. Permintaan ganti kerugian dan/atau rehabilitasi akibat tidak sahnya penangkapan atau penahanan atau akibat tidak sahnya penghentian penyidikan atau penuntutan diajukan oleh tersangka atau pihak ketiga yang berkepentingan kepada ketua pengadilan negeri dengan menyebutkan alasannya.

Hasil wawancara dengan Kisyadi selaku BPKP Perwakilan Lampung menyatakan bahwa bahwa pada hakikatnya Praperadilan merupakan kewenangan pengadilan untuk memberikan kesempatan kepada tersangka yang sedang menjalani proses peradilan tetapi belum mendapat keputusan hukum tetap sebagai perlindungan atas adanya 
upaya paksa yang dilakukan oleh penyidik berupa penangkapan, penahanan, penggeledahan, dan penyitaan sesuai dengan undangundang.

Upaya paksa tersebut hakikatnya merupakan perlakuan yang bersifat:

a. Tindakan paksa yang dibenarkan undang-undang demi kepentingan pemeriksaan tindak pidana yang disangkakan kepada tersangka

b. Sebagai tindakan paksa yang dibenarkan hukum dan undangundang, setiap tindakan paksa dengan sendirinya merupakan perampasan kemerdekaan dan kebebasan serta pembatasan terhadap hak asasi manusia.

Hasil wawancara Aris Fitria Wijaya dengan selaku Hakim Pengadilan Negeri Menggala menyatakan bahwa kedudukan tersangka dalam Kitab Undang-Undang Hukum Acara Pidana adalah sebagai subjek, dalam setiap pemeriksaan harus diperlakukan dalam kedudukan sebagai manusia yang mempunyai harkat, martabat dan harga diri tersangka. Hal tersebut terkait Azas Praduga Tidak Bersalah (presumtion of innocence) sebagaimana tercantum dalam Pasal 8 UndangUndang Nomor 48 Tahun 2009 tentang Kekuasaan Kehakiman berbunyi setiap orang yang disangka, ditangkap, ditahan, dituntut, atau dihadapkan di depan pengadilan wajib dianggap tidak bersalah sebelum ada putusan pengadilan yang menyatakan kesalahannya dan telah memperoleh kekuatan hukum tetap.

Pada dasarnya dalam Kitab Undang-Undang Hukum Acara Pidana tidak mengatur tentang praperadilan atas status tersangka, sebagai konsekuensi hal tersebut maka ada dua keadaan yaitu sah atau tidaknya permintaan praperadilan yang diajukan oleh tersangka.

Praperadilan merupakan suatu pengertian hukum tersendiri yang berkenaan dengan penggunaan upaya paksa dalam proses penyidikan atau penuntutan serta akibat hukum yang timbul darinya. Pasal 77 jo Pasal 1 angka 10 Kitab Undang- Undang Hukum Acara Pidana yang dikenal sebagai ketentuan yang mengatur tentang praperadilan Berdasarkan pasal tersebut, sah atau tidaknya penetapan tersangka bukanlah objek yang dapat diajukan dalam sebuah praperadilan. Penetapan tersangka, walaupun merupakan bagian dari tahap penyidikan berdasarkan Kitab UndangUndang Hukum Acara Pidana bukan merupakan objek dari praperadilan.

Berdasarkan uraian di atas, maka dapat dianalisis akibat hukum dikabulkannya permohonan pra peradilan tentang sah tidaknya penetapan tersangka oleh penyidik berdasarkan pertimbangan bahwa penetapan status tersangka merupakan bagian dari penyidikan dan Pasal 82 ayat (3) Kitab UndangUndang Hukum Acara Pidana bahwa dalam hal menetapkan bahwa suatu penangkapan atau penahanan tidak sah, maka penyidik atau jaksa penuntut umum pada tingkat pemeriksaan masing-masing harus segera membebaskan tersangka. Putusan tersebut tentunya menjadi jurisprudensi yang dapat dipakai oleh Hakim lain sebagai acuan dalam membuat putusan dalam lembaga Praperadilan. Apabila dikeluarkan Surat Perintah Penghentian (SP3), maka perkara digelarkan lalu dibuat Surat Perintah Penghentian (SP3). Sedangkan apabila perkara dilanjutkan, maka harus dibuat sura perintah penyidikan lanjutan. 


\section{Penutup}

\section{Kesimpulan}

Berdasarkan hasil penelitian dan pembahasan maka dapat disimpulkan sebagai berikut:

a. Proses penyidikan tindak pidana korupsi dana program penyediaan dan pengembangan sarana dan prasarana pertanian di Dinas Pertanian, Perkebunan dan Kehutanan Kabupaten Tulang Bawang sudah sesuai dengan ketentuan yang ada di dalam Kitab Undang-Undang Hukum Acara Pidana, khususnya Pasal 77 KUHAP yang mengatur objek Praperadilan, dimana Pengadilan Negeri Menggala $C q$. Hakim Tunggal Praperadilan yang memeriksa dan mengadili permohonan ini berpendapat lain, mohon putusan yang seadil-adilnya (ex aequo et bono). Penetapan tersangka atas diri pemohon yang dilakukan oleh termohon dalam perkara tindak pidana korupsi dana program penyediaan dan pengembangan sarana dan prasarana pertanian di Dinas Pertanian, Perkebunan dan Kehutanan Kabupaten Tulang Bawang Penetapan a quo tidak mempunyai kekuatan Hukum yang mengikat.

b. Kewenangan mengadili oleh Hakim Pra Peradilan tentang penetapan seseorang menjadi tersangka dalam perkara tindak pidana korupsi dana program penyediaan dan pengembangan sarana dan prasarana pertanian pasca Putusan MK Nomor 21/PUU-XII/2014 berdasarkan Putusan Perkara Nomor 3/Pid/Pra/2018/PN.Mgl adalah Hakim telah mempertimbangkan bahwa Pengadilan Negeri Menggala Cq.
Hakim Tunggal Praperadilan yang memeriksa dan mengadili permohonan ini berpendapat lain, mohon putusan yang seadil-adilnya (ex aequo et bono).

c. Akibat hukum dikabulkannya permohonan pra peradilan tentang sah tidaknya penetapan tersangka oleh penyidik berdasarkan pertimbangan bahwa penetapan status tersangka merupakan bagian dari penyidikan dan Pasal 82 ayat (3) Kitab Undang-Undang Hukum Acara Pidana bahwa dalam hal menetapkan bahwa suatu penangkapan atau penahanan tidak sah, maka penyidik atau jaksa penuntut umum pada tingkat pemeriksaan masing-masing harus segera membebaskan tersangka. Putusan tersebut tentunya menjadi jurisprudensi yang dapat dipakai oleh Hakim lain sebagai acuan dalam membuat putusan dalam lembaga Praperadilan. Apabila dikeluarkan Surat Perintah Penghentian (SP3), maka perkara digelarkan lalu dibuat Surat Perintah Penghentian (SP3). Sedangkan apabila perkara dilanjutkan, maka harus dibuat sura perintah penyidikan lanjutan.

\section{Saran}

a. Diharapkan kepada Penyidik disarankan untuk melaksanakan penyidikan secara berdasarkan ketentuan hukum acara pidana yang berlaku dalam rangka mengantisipasi permohonan praperadilan, sehingga tindakan yang dilakukan oleh penyidik dapat berjalan efektif dan efisien dalam rangka penegakan hukum. Apabila dikeluarkan Surat Perintah Penghentian (SP3), maka perkara digelarkan lalu dibuat Surat Perintah Penghentian (SP3). 
Sedangkan apabila perkara dilanjutkan, maka harus dibuat sura perintah penyidikan lanjutan.

b. Kepada Hakim praperadilan disarankan untuk tetap menjaga objektivitas dalam memutus permohonan praperadilan, dalam rangka memberikan keadilan bagi pihak-pihak yang dirugikan dalam proses penanganan perkara pidana oleh aparat penegak hukum.

c. Kepada aparat penegak hukum khususnya penyidik dalam melaksanakan tugas dan kewajibannya, sebelum menetapkan seseorang menjadi tersangka sebaiknya terpenuhi terlebih dahulu 2 (dua) alat bukti yang cukup. Hal ini demi menjaga kredibilitas aparat penegak hukum dalam menentukan sikap sebelum terjadinya kesalahan yang merenggut hak seseorang

\section{DAFTAR PUSTAKA}

\section{A. BUKU-BUKU}

Adhami Chazawi. 2008. Hukum Pembuktian Tindak Pidana Korupsi. Alumni, Bandung.

Ahmad Rifai. 2015. Penemuan Hukum oleh Hakim dalam Persfektif Hukum Progresif. Edisi Revisi Sinar Grafika, Jakarta.

Alfitra. 2011. Hukum Pembuktian dalam beracara Pidana. Perdata dan Korupsi di Indonesia. Raih Asa Sukses, Jakarta.

Bambang Purnomo. 1988. Pola Dasar Teori dan Azas Umum Hukum Acara Pidana. Liberty, Yogyakarta.

Barda Nawawi Arief. 1996. Bunga Rampai Kebijakan Hukum Pidana. Citra Aditya Bhakti, Bandung.
Budi Winarno. 2002. Teori dan Proses Kebijakan Publik.Medpress, Jakarta. hlm. 17.

Eva Achjani Zufa. Indriyanto Seno Adji. 2011. Pergeseran Paradigma Pemidanaan. Lubuk Agung, Bandung.

Hans Kelsen. 2013. Teori Umum Tentang Hukum dan Negara. Edisi Terjemahan oleh A. Prihatno. Penerbit Nusa Media, Bandung.

Hendar Soetarna. 2011. Hukum Pembuktian dalam Acara Pidana. Alumni, Bandung.

Leden Marpaung. 1992. Proses Penanganan Perkara Pidana. Sinar Grafika, Jakarta.

M.Yahya Harahap. 2012. Hukum Acara Perdata. Sinar Grafika, Jakarta.

Mardjono Reksodiputro. 1999. Hak Asasi Manusia dalam sistem Peradilan Pidana. Pusat Pelayanan Keadilan dan Pengabdian Universitas Indonesia, Jakarta.

Mochtar Kusumaatmadja. 2002. Hukum. Masyarakat dan Pembinaan Hukum Nasional. Binacipta, Jakarta.

O.C. Kaligis dkk. 1997. Praperadilan Dalam Kenyataan. Djambatan, Jakarta.

P.A.F. Lamintang. dan C. Djisman Samosir. 1981. Delik-Delik Khusus. Tarsito, Bandung.

S. Tanusubroto. 2010. Peranan Prapeeradilan Dalam Hukum Acara Pidana. Alumni, Bandung.

Soejono Soekanto. 1991. Metode Penelitian Sosial. UI Press, Jakarta.

Wirjono Prodjodikoro. 2006. AsasAsas Hukum Pidana di 
Indonesia. Refika Aditama, Jakarta.

\section{B. UNDANG-UNDANG DAN PERATURAN-PERATURAN LAINNYA}

Undang-Undang Dasar 1945 hasil Amandemen Keempat.

Undang-Undang Nomor 1 Tahun 1946 Jo. Undang-Undang Nomor 73 Tahun 1958 tentang Pemberlakukan Peraturan Hukum Pidana di Seluruh Indonesia (KUHP).

Undang-Undang Nomor 8 Tahun 1981 tentang Hukum Acara Pidana (KUHAP).

Undang-Undang Nomor 28 Tahun 1999 tentang Penyelenggaraan Negara Yang Bersih dan Bebas dari KKN.

Undang-Undang Nomor 31 Tahun 1999 Jo. Undang-Undang Nomor 20 Tahun 2001 tentang Pemberantasan Tindak Pidana Korupsi.

Undang-Undang Nomor 2 Tahun 2002 tentang Kepolisian Negara Republik Indonesia.

Undang-Undang Nomor 30 Tahun 2002 tentang Komisi Pemberantasan Tindak Pidana Korupsi.

Undang-Undang Nomor 17 Tahun 2003 tentang Keuangan Negara.

Undang-Undang Nomor 1 Tahun 2004 tentang Perbendaharan Negara.

Undang-Undang Nomor 16 Tahun 2004 tentang Kejaksaan Republik Indonesia.

Undang-Undang Nomor 15 Tahun 2006 tentang Badan
Pemeriksaan Keuangan (BPK)

Undang-Undang Nomor 48 Tahun 2009 tentang Perubahan atas Undang-Undang Nomor 4 Tahun 2004 tentang Kekuasaan Kehakiman Republik Indonesia.

Peraturan Pemerintah Nomor 92 Tahun 2015 tentang Perubahan Kedua Peraturan Pemerintah Nomor 27 Tahun 1983 Jo. Peraturan Pemerintah Nomor 58 Tahun 2010 tentang Pedoman Pelaksanaan KUHAP.

Peraturan Pemerintah Pengganti Undang-Undang (Perppu) Nomor 1 Tahun 2015 tentang Komisi Pemberantasan Tindak Pidana Korupsi.

Peraturan Presiden Republik Indonesia Nomor 192 Tahun 2014 tentang Badan Pengawasan Keuangan dan Pembangunan.

Putusan MK Nomor 21/PUUXII/2014.

\section{SUMBER LAIN}

Ali Muhammad. 1980. Kamus Lengkap Bahasa Indonesia Modern. Pustaka Amani, Jakarta.

JCT Simorangkir et.al. 2003. Kamus Hukum. Sinar Grafika, Jakarta.

Lukman Hakim. 1987. Kamus Bahasa Inggris. Tangga Pustaka, Jakarta.

Website:

www.pemantauperadilan.com - Praperadilan sebagai Lembaga Pengawas Kinerja. Theodora YSP. S.H.. diunduh tanggal 1 Oktober 2018. Pukul 18.45 WIB 